\title{
Review \\ G Protein-Coupled Estrogen Receptor in Cancer and Stromal Cells: Functions and Novel Therapeutic Perspectives
}

\author{
Richard A. Pepermans ${ }^{1}$, Geetanjali Sharma ${ }^{1,2}$ (D) and Eric R. Prossnitz ${ }^{1,2,3, *}$ \\ 1 Division of Molecular Medicine, Department of Internal Medicine, University of New Mexico Health Sciences \\ Center, Albuquerque, NM 87131, USA; rpepermans@salud.unm.edu (R.A.P.); gsharma@salud.unm.edu (G.S.) \\ 2 Center of Biomedical Research Excellence in Autophagy, Inflammation and Metabolism, University of New \\ Mexico Health Sciences Center, Albuquerque, NM 87131, USA \\ 3 University of New Mexico Comprehensive Cancer Center, University of New Mexico Health Sciences Center, \\ Albuquerque, NM 87131, USA \\ * Correspondence: eprossnitz@salud.unm.edu; Tel.: +1-505-272-5647
}

Citation: Pepermans, R.A.; Sharma, G.; Prossnitz, E.R. G Protein-Coupled Estrogen Receptor in Cancer and Stromal Cells: Functions and Novel Therapeutic Perspectives. Cells 2021, 10, 672. https://doi.org/10.3390/ cells10030672

Academic Editor: Stefania Merighi

Received: 22 January 2021

Accepted: 10 March 2021

Published: 17 March 2021

Publisher's Note: MDPI stays neutral with regard to jurisdictional claims in published maps and institutional affiliations.

Copyright: (C) 2021 by the authors. Licensee MDPI, Basel, Switzerland. This article is an open access article distributed under the terms and conditions of the Creative Commons Attribution (CC BY) license (https:// creativecommons.org/licenses/by/ $4.0 /)$.

\begin{abstract}
Estrogen is involved in numerous physiological and pathophysiological systems. Its role in driving estrogen receptor-expressing breast cancers is well established, but it also has important roles in a number of other cancers, acting both on tumor cells directly as well as in the function of multiple cells of the tumor microenvironment, including fibroblasts, immune cells, and adipocytes, which can greatly impact carcinogenesis. One of its receptors, the G protein-coupled estrogen receptor (GPER), has gained much interest over the last decade in both health and disease. Increasing evidence shows that GPER contributes to clinically observed endocrine therapy resistance in breast cancer while also playing a complex role in a number of other cancers. Recent discoveries regarding the targeting of GPER in combination with immune checkpoint inhibition, particularly in melanoma, have led to the initiation of the first Phase I clinical trial for the GPER-selective agonist G-1. Furthermore, its functions in metabolism and corresponding pathophysiological states, such as obesity and diabetes, are becoming more evident and suggest additional therapeutic value in targeting GPER for both cancer and other diseases. Here, we highlight the roles of GPER in several cancers, as well as in metabolism and immune regulation, and discuss the therapeutic value of targeting this estrogen receptor as a potential treatment for cancer as well as contributing metabolic and inflammatory diseases and conditions.
\end{abstract}

Keywords: estrogen; GPER; cancer; stroma; metabolism; obesity

\section{Introduction}

Estrogen, the female sex hormone that is best known for its role in female reproduction and mammary gland development, also plays a role in many other physiological systems, including metabolism and the cardiovascular and immune systems [1,2]. In addition to its role in females, estrogen also plays a role in male physiology [3]. Besides regulating tumor cell properties, it also has effects on diverse cells of the tumor microenvironment or stroma, including fibroblasts, immune cells, and adipocytes [4]. It exerts its function through three known estrogen receptors (ERs): $\mathrm{ER} \alpha, \mathrm{ER} \beta$, and the $\mathrm{G}$ protein-coupled estrogen receptor (GPER, formerly known as GPR30) [5-7]. Aside from its physiological roles, estrogen is also involved in various diseases, among the best-known being breast cancer [8]. For decades, estrogen has been recognized to be the major driver of ER-positive breast cancers through the activation of ER $\alpha$ [9]. This has led to FDA approval of several ER $\alpha$-targeting drugs, such as tamoxifen and fulvestrant, and the development of various next-generation ER $\alpha$-targeting antagonists in various stages of clinical development [10-16].

Although ER $\alpha$ is the main driver of the majority $(\sim 70 \%)$ of primary breast cancers, GPER, over the past decade, has gained interest as a potential contributor to the development of endocrine resistance in the breast cancer relapse setting $[9,17,18]$. This is in part 
due to observations that tamoxifen, a standard-of-care drug for ER $\alpha$-positive breast cancers, cross-activates GPER $[19,20]$. GPER has also been implicated in other cancers as either a proor anti-tumorigenic factor and observations, specifically in the melanoma field, have led to the initiation of a Phase I clinical trial for a GPER-targeted drug (NCT04130516) [21-23].

In addition to cancer, growing evidence reveals roles for GPER in normal and pathophysiological metabolism [24-28]. Obesity has reached epidemic proportions and increases the risk of conditions associated with metabolic syndrome, namely high blood sugar (i.e., hyperglycemia, in the form of diabetes), high blood pressure (hypertension), and abnormal lipid levels (dyslipidemia). Furthermore, obesity also increases the risk of developing many types of cancer, including pancreatic and liver cancer [29]. Importantly, GPER has been shown to regulate body weight and glucose/lipid homeostasis and its activation exerts anti-obesity and anti-diabetic effects in multiple murine models, making it a potential therapeutic target for treating obesity and/or diabetes [25].

In this review, we discuss the direct roles of GPER in several cancers, as well as indirect roles based on obesity and metabolism- and immune-related stromal cells, suggesting multiple therapeutic roles for GPER-targeted drugs in the treatment of cancer.

\section{Estrogen Receptors}

Estrogen has three known receptors in the body: $\mathrm{ER} \alpha, \mathrm{ER} \beta$, and GPER. $\mathrm{ER} \alpha$ and $\mathrm{ER} \beta$, the so-called classical ERs, are nuclear hormone receptors that act largely as ligand-activated transcription factors [30-32]. They are expressed in various tissues with some tissues expressing both receptor subtypes, while others express predominantly one subtype. For example, ER $\alpha$ is expressed in the breast (luminal epithelial cells), bone, and uterus whereas ER $\beta$ is expressed in the breast (stromal myoepithelial cells), colon, and lung [32-34]. ER $\alpha$ and $E R \beta$ regulate gene expression through either binding directly to DNA or indirectly through recruitment to other transcription factors $[1,32]$. This gene regulation results in either an increase or decrease in target gene expression, with the majority of target genes in fact showing a decrease in gene expression [35]. Aside from their ability to regulate genomic signaling (on the scale of tens of minutes to hours), ER $\alpha$ and ER $\beta$ also induce rapid, non-genomic signaling (on the scale of seconds to minutes), leading to multiple cellular responses, including activation of kinase pathways and $\mathrm{Ca}^{2+}$ mobilization [36-39]. This rapid signaling is believed to occur through a fraction of splice variants of $E R \alpha$ and ER $\beta$ or palmitoylated receptors at the plasma membrane rather than through the full-length cytoplasmic/nuclear versions of the receptors that are chiefly responsible for the genomic signaling $[37,38]$.

Unlike the classical ERs, the third known estrogen receptor, GPER, is a G proteincoupled receptor (GPCR) that predominantly induces rapid, non-genomic estrogen signaling [7]. Originally cloned in the late 1990s, its activation leads to a multitude of downstream, rapid signaling events, including $\mathrm{Ca}^{2+}$ mobilization, cyclic adenosine monophosphate (cAMP) synthesis, and activation of kinase pathways, such as the phosphatidylinositol3-kinase (PI3K) and mitogen-activated protein kinase (MAPK) pathways [7,40-43]. Interestingly, GPER appears not to directly activate the PI3K and MAPK signaling pathways, but rather leads to their activation via the trans-activation of the epidermal growth factor receptor (EGFR) in a mechanism involving the cleavage of heparin-bound EGF on the plasma membrane [41]. GPER is not unique in this mechanism of cell activation as many GPCRs trans-activate EGFR [44-46]. This was an interesting discovery for GPER given that, in many cell types, GPER is mainly localized to the endoplasmic reticulum and not to the plasma membrane, where EGFR is found [7]. However, several groups have reported lower levels of GPER at the plasma membrane in addition to intracellular compartments (endoplasmic reticulum and Golgi apparatus), even including the nucleus [47-50]. In the nucleus, it has been hypothesized to act as a transcription factor, possibly in a complex with EGFR, but the mechanism by which this could occur is not understood [50]. Although it remains unclear whether GPER can act as a transcription factor, GPER can regulate gene expression, through signaling pathways involving activation of transcription factors such 
as cAMP-response element binding protein (CREB); however, gene expression changes in response to GPER generally involve far fewer genes than those of ER $\alpha$ and ER $\beta$ [40]. GPER, through its activation by estrogen, induces the expression of genes, such as c-fos, in various cell types, including thyroid [51], endometrial [52], and ER $\alpha / \beta$-negative/GPER-positive breast cancer cell lines [53]. Several of these reports have also shown that knockdown of GPER attenuates E2-induced expression of c-fos. Aside from c-fos, activation of GPER also induces expression of genes such as CCN2 (connective tissue growth factor (CTGF)) and $\mathrm{Bcl}-2[40,53]$.

$\mathrm{ER} \alpha, \mathrm{ER} \beta$, and GPER can all induce genomic and non-genomic signaling pathways, albeit to different extents, with some of these pathways overlapping. Therefore, it can be difficult to distinguish an ER-induced signal from a GPER-induced signal. Selective compounds to these receptors have aided in better understanding the individual roles of these receptors.

\section{Compounds That Selectively Target GPER}

For decades, small molecule compounds have been used to study the roles of individual receptors within a receptor family. In the case of the classical ERs, this has been challenging due to large structural similarities between the ligand binding pockets of ER $\alpha$ and $E R \beta$, resulting in a high degree of ligand cross-reactivity between the two receptor subtypes [19,32]. Nevertheless, ER subtype-biased ligands, such as propylpyrazoletriol (PPT) and diarylpropionitrile (DPN), have been developed [54,55]. PPT acts as an ER $\alpha$-selective agonist that shows $\sim 410$-fold binding selectivity towards ER $\alpha$ over ER $\beta$ whereas DPN, an ER $\beta$-selective agonist, exhibits $\sim 70$-fold selectivity to ER $\beta$ over ER $\alpha$.

Despite the overall structural differences between the classical estrogen receptors (transcription factors) and GPER (a GPCR), cross-reactivity of ER $\alpha / \beta$ ligands towards GPER is also prevalent. In fact, until recently, $\mathrm{ER} \alpha / \beta$ ligands, including the clinicallyused ER $\alpha$-targeting drugs tamoxifen, raloxifene, and fulvestrant, show binding and/or activity towards GPER $[19,20]$. This lack of ER ligand selectivity has been challenging when studying estrogen signaling, due to partially overlapping signaling pathways between the classical ERs and GPER. We recently identified the first known ER $\alpha / \beta$-selective ligand, termed AB-1, that shows negligible binding to GPER at concentrations up to $10 \mu \mathrm{M}$ [56]. It acts as an agonist of $\mathrm{ER} \alpha$ and $E R \beta$, while neither inducing nor inhibiting GPER-mediated signaling pathways. Due to the prior lack of truly ER $\alpha / \beta$-selective compounds, such selective compounds should aid in better differentiating the roles of ER $\alpha / \beta$ versus GPER in systems that express both receptors.

Compounds with an inverse binding profile (i.e., high selectivity for GPER over $\mathrm{ER} \alpha / \beta)$ also exist. In 2006, the first GPER-selective agonist G-1 was identified, with high binding affinity towards GPER and negligible binding to $\operatorname{ER} \alpha$ and $\operatorname{ER} \beta$ at concentrations up to $10 \mu \mathrm{M}$ [36]. This was followed by the discovery of the first GPER-selective antagonist, G15 in 2009 [57], and the even more selective GPER antagonist, G36 in 2011 [58]. These compounds show negligible or no binding and/or activity towards the classical ERs at concentrations up to $10 \mu \mathrm{M}$. In 2012, Maggiolini and colleagues identified two GPERselective agonists, termed GPER-L1 and GPER-L2, that display 100-fold poorer affinity for GPER versus G-1 [59]. Recently, following an in silico pharmacophore screen, several indole-thiazole derivates were identified that act as selective GPER agonists [60]. These compounds show no binding to ER $\alpha / \beta$ and can induce cAMP synthesis in HL-60 cells, which can be blocked by co-treatment with G15. Whether these indole-thiazole derivates show any agonism in other GPER-mediated pathways is unknown.

\section{GPER in Breast and Other Cancers}

\subsection{Breast Cancer}

ER $\alpha$-positive breast cancers make up the majority of breast cancer subtypes seen in the clinic [9]. Endocrine therapy, using selective estrogen receptor modulators (SERMs), such as tamoxifen, selective estrogen receptor downregulators (SERDs), such as fulvestrant, 
or aromatase inhibitors (AIs), has prolonged the lives of millions of ER $\alpha$-positive breast cancer patients and has been a great clinical success [10]. However, $30 \%$ of women develop endocrine resistance to their therapy, with some reports indicating this number to be even higher $[10,61]$. Several mechanisms have been described to account for the development of endocrine resistance [18,62-65]. In the case of resistance to tamoxifen, a standard-ofcare drug in the clinic, numerous reports, both clinical and non-clinical, have pointed to GPER as a potential player in the development of resistance. Specifically, increased GPER expression was observed in breast cancer metastases compared to their matched primary tumors $[17,66]$. Increased GPER expression was only observed in metastatic tumor samples of women who had been treated with tamoxifen, but not in metastases of women who were not prescribed tamoxifen, indicating a possible role for GPER in the development of relapse breast cancer [66]. To this end, GPER shows a positive association with metastasis [67], which is supported by the observation that in a breast cancer mouse model, GPER-deficiency results in decreased metastases to the lung [68]. Furthermore, GPER expression correlates negatively with progression-free survival [66], but this is contradicted by findings describing a non-statistically significant, positive correlation between GPER expression and disease-free progression $(p=0.07-0.12)$ [69]. Primary ER $\alpha$-positive breast tumors, that co-express GPER, shrink significantly more when the patient is treated with an AI-based primary endocrine therapy versus a tamoxifen-based primary therapy and this difference is absent in GPER-negative primary ER $\alpha$-positive breast tumors [70]. Moreover, an AI-based therapy resulted in better disease-free progression for breast cancer patients compared to a tamoxifen-based therapy [69]. The observed difference between AI and tamoxifen treatment could be due to the different mechanisms of action of the drugs, namely AIs decrease circulating E2 levels (and do not affect GPER directly), whereas tamoxifen directly inhibits ER $\alpha$ and directly activates GPER [64]. This activation of GPER leads to pro-survival signaling in cancer cells; possibly decreasing the overall efficacy of tamoxifen compared to an AI. Collectively, these multiple lines of clinical data suggest a role for GPER in the development or sustainability of tamoxifen resistance.

In vitro data also support a role for GPER in the development of tamoxifen-resistance. Tamoxifen induces the in vitro proliferation of tamoxifen-resistant MCF-7 cells through a GPER-dependent pathway $[17,18]$. This proliferative effect was blocked through GPER knockdown or by co-treatment with the GPER-selective antagonist, G15 [17,57]. Tamoxifen also induces, through a GPER-dependent pathway, proliferation (or activation of proliferative factors) of other cell types, including endometrial [20,71] and thyroid [51] cancer cells. Such activation of GPER by tamoxifen is supported by binding data showing that tamoxifen binds and cross-activates GPER [19,20,72]. Aside from inducing proliferation, tamoxifen-induced cross-activation of GPER also induces breast cancer cell migration [73] and increases aromatase expression in tamoxifen-resistant cells [74]. The latter mechanism could induce an increase in local estrogen levels sufficient to counteract the inhibitory effects of tamoxifen in relapse tumors. In vivo, GPER also contributes to tamoxifen resistance in MCF-7 cells. Tamoxifen-resistant xenografts became sensitive to tamoxifen when mice were treated with a combination of tamoxifen and G15 [17]. Importantly, these tumors were unaffected by the individual monotherapies, thereby implicating GPER in the observed tamoxifen resistance. Collectively, the aforementioned observations implicate GPER in the development and/or sustainability of tamoxifen resistance in ER $\alpha$-positive breast cancers (Figure 1). 


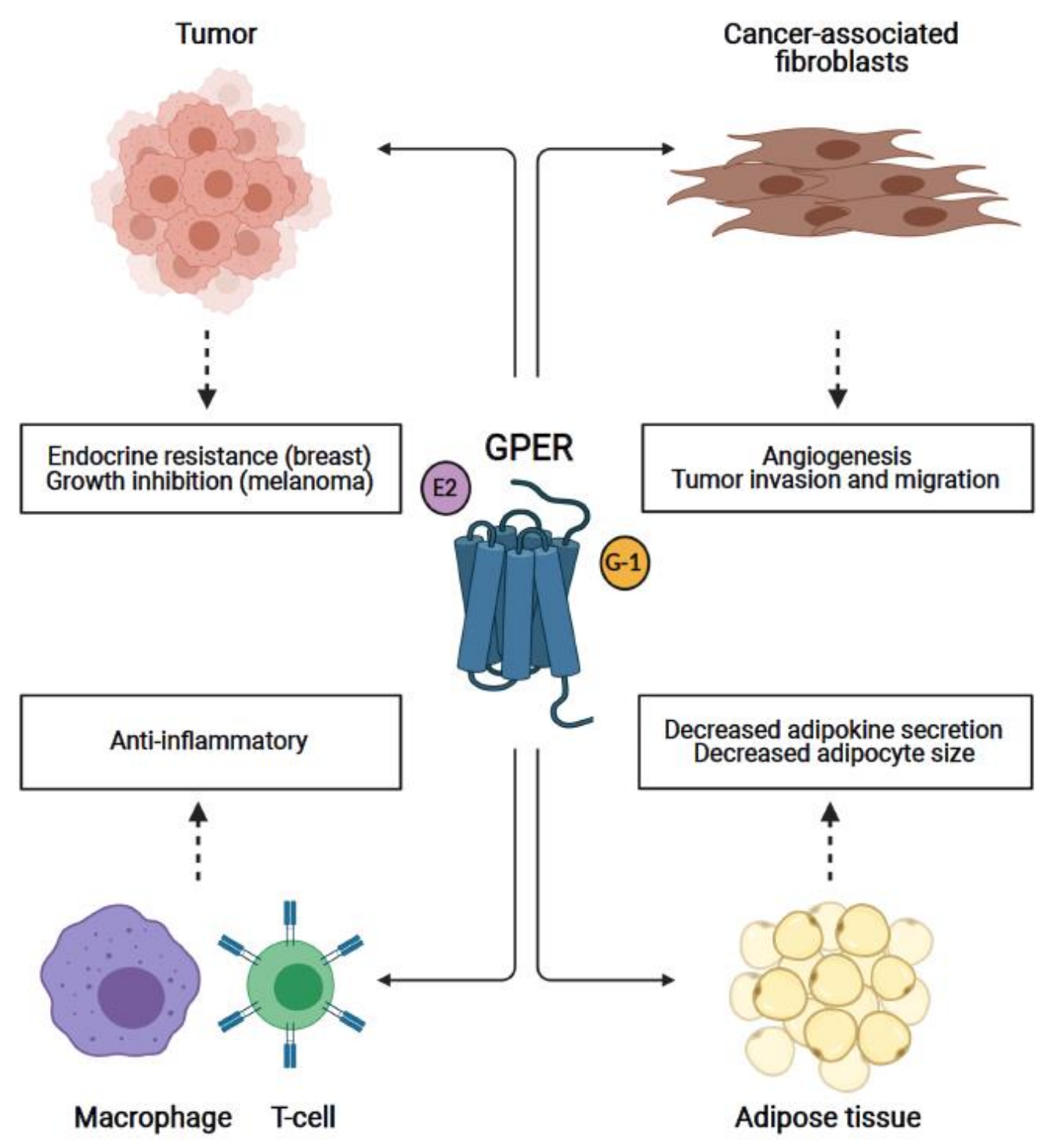

Figure 1. Effects of G protein coupled estrogen receptor (GPER) signaling in multiple tissue types that affect carcinogenesis. GPER signaling induces various responses in different tissue types that can promote or inhibit tumor growth and progression. In estrogen receptor (ER)-positive breast cancers, GPER activation may contribute to the development of endocrine resistance. However, in a melanoma setting, GPER signaling (through G-1 activation) inhibits tumor growth and increases the efficacy of anti-programmed cell death protein-1 (PD-1) immunotherapy. In cancer-associated fibroblasts (in breast cancer), GPER signaling leads to a pro-tumorigenic environment through increased secretion of angiogenic (e.g., vascular endothelial growth factor (VEGF)) and migratory (e.g., connective tissue growth factor (CTGF)) factors that promote tumor angiogenesis, migration, and invasion. In immune cells, GPER plays an anti-inflammatory role by decreasing the secretion of various pro-inflammatory cytokines (e.g., interleukin-1 $\beta$ (IL-1 $\beta$ ), tumor necrosis factor- $\alpha$ (TNF- $\alpha$ ) and interferon- $\gamma$ (IFN- $\gamma$ )), which could prove to be of therapeutic value in carcinogenesis and autoimmune diseases, such as multiple sclerosis, as well as in adipose tissue resulting in reduced adipokine secretion. Furthermore, G-1-induced GPER signaling leads to reduced adiposity and smaller adipocytes, which in conjunction with decreased adipokine secretion, could limit availability of adipokines and nutrients to tumors, thereby inhibiting tumor growth and progression.

\subsection{Melanoma}

Historically, men have had both a higher risk of developing melanoma and a worse prognosis for this disease than women $[75,76]$. This had led to the hypothesis that sex hormones play a role in the observed sex differences in both melanoma incidence rates as well as outcomes. A role for sex hormones in melanocyte function is suggested by their association with hyperpigmentation (melasma), in which women commonly develop 
darker pigmentation during pregnancy, when estrogen levels are elevated [77]. To this end, two groups have shown, using both genetic and pharmacological approaches, that GPER is required for estrogen-mediated melanogenesis (pigment formation), but whether GPER plays a role in melanoma, was unknown [78,79]. In the clinic, tamoxifen provides a benefit, in combination with chemotherapy, in the treatment of metastatic melanoma in women [80]. However, these observations have been contradicted by a meta-analysis showing that while tamoxifen does improve initial response to chemotherapy, it does not reduce the overall 1- and 2-year mortality in advanced melanoma [81]. Interestingly, the meta-analysis study did report better response rates in trials that consisted predominantly of women.

In vitro data support the observations that tamoxifen has some benefit in treating melanoma. For example, cell-based data reveal that tamoxifen inhibits proliferation of human and mouse melanoma cells, while also inhibiting metastasis of melanoma in vivo [82-85]. Furthermore, treating murine melanoma cells with the GPER-selective agonist, G-1, inhibits proliferation of these cells and treatment with tamoxifen also results in similar cellular responses [84]. Importantly, knockdown of GPER abrogated the observed effects induced by both G-1 and tamoxifen, indicating that the anti-proliferative effects of these compounds occurred through a GPER-mediated pathway, implying that activation of GPER brought about anti-proliferative effects in melanoma.

In the past decade, immune checkpoint inhibition has produced great clinical benefits for the treatment of advanced melanoma using agents such as ipilimumab [86,87]. Nevertheless, about $50 \%$ of melanoma patients do not respond to this class of treatment [88]. Ridky and colleagues examined whether estrogen, specifically through GPER, could impact the efficacy of anti-PD-1 immunotherapy in melanoma therapy [22]. Co-treatment with an anti-PD-1 antibody and G-1 not only shrank tumors, but also significantly improved survival of melanoma-bearing mice. They identified that activation of GPER by G-1, in melanoma xenografts, induces a decrease in c-Myc levels, which results in decreased cell surface expression of programmed cell death ligand-1 (PD-L1) and increased cell surface levels of human leukocyte antigen (HLA), which together lead to improved immune recognition of melanoma tumor cells. These observations suggest great promise in targeting GPER for the treatment of melanoma in combination with established anti-PD-1 immunotherapies (Figure 1). In fact, this work was has led to the initiation of the first Phase I clinical trial of G-1 (NCT04130516). That this combination therapy may extend beyond melanoma is suggested by murine models of pancreatic cancer that also revealed promising results [89].

\subsection{Other Cancers}

Aside from its expression in breast cancer and melanoma, GPER is also expressed in numerous other cancer cell lines and tumors, including endometrial [20,52,90], thyroid [51], ovarian [91,92], testicular [93,94], prostate [95], pancreatic [89], and lung [2,96]. Activation of GPER generally promotes proliferation and proliferative signaling pathways in endometrial [52], thyroid [51], and ovarian [91] cancer cell lines, although inhibition of proliferation has been reported in breast [97] and pancreatic cell lines [89]. The majority of these findings employed cell lines, so the role of GPER remains unclear in certain primary tumors types. Importantly, GPER expression in endometrial [98] and ovarian [99] tumors predicts poor survival, suggesting a pro-tumorigenic role for GPER in these types of tumors. GPER also appears to play a pro-tumorigenic/pro-survival role in certain cancer stem cells (CSCs), specifically breast CSCs [100]. Activation of GPER in ER-negative/progesterone receptorpositive breast CSCs increases the viability of these breast CSCs via a GPER/(protein kinase A (PKA)/BCL2-associated agonist of cell death (BAD) pathway [100]. Importantly, knockdown of GPER in these CSCs decreased their viability and tumorigenicity, suggesting a potential role for GPER as a potential therapeutic target for targeted killing of breast CSCs. 


\section{GPER in Cancer-Associated Fibroblasts}

Fibroblasts, specifically cancer-associated fibroblasts (CAFs), make up a significant fraction of stromal cells in the tumor microenvironment and play an important role in various stages of cancer progression [101]. GPER is expressed in breast CAFs, suggesting a further role for GPER, through CAFs, in breast tumor progression $[50,102,103]$. Both estrogen and G-1 induce increased expression of hypoxia inducible factor- $1 \alpha(\mathrm{HIF}-1 \alpha)$ and the angiogenic vascular endothelial growth factor (VEGF) in breast CAFs, with the latter occurring via a HIF-1 $\alpha$-dependent mechanism [104]. Increased VEGF expression promotes tumor angiogenesis; thus GPER may contribute to such a pro-tumorigenic environment [105]. In a recent report, insulin growth factor 1 (IGF1) induced upregulation of GPER, HIF-1 $\alpha$, and VEGF in breast CAFs [106]. Importantly, knockdown of GPER or HIF- $1 \alpha$ abolished the observed IGF1-induced upregulation of VEGF, further demonstrating the contribution of GPER in a CAF-induced angiogenic tumor microenvironment.

In addition to contributing to a pro-angiogenic microenvironment, GPER, through breast CAFs, has also been implicated in promoting tumor progression by increasing migration and invasion of breast cancer cells (Figure 1). A pro-migratory role for GPER in breast CAFs was demonstrated as a result of the hypoxia-driven expression of VEGF, interleukin-6 (IL-6), and CTGF, with enhanced invasion of breast cancer cells occurring in a GPER/CTGF-dependent manner [107]. Estrogen and G-1 both increase expression of fibroblast growth factor 2 (FGF2) in breast CAFs [108], an effect inhibited by co-treatment with G15 or knockdown of GPER. Importantly, conditioned medium from these stimulated CAFs induced activation of the FGF receptor 1 (FGFR1) on triple negative breast cancer cells in vitro, which subsequently promoted increased cell migration and invasion. A similar paracrine signaling mechanism involves GPER-mediated increases in expression of interleukin 1 beta (IL-1 $\beta$ ) and IL-1 receptor 1 (IL-1R1) on CAFs and triple-negative breast cancer cells, respectively, resulting in increased migration of breast cancer cells [109]. Collectively, these reports suggest that breast CAFs, through a GPER-mediated pathway, can induce paracrine signaling that promotes tumor migration and invasion.

Breast CAFs may also promote tumor progression by increasing local concentrations of estrogen. Tamoxifen and G-1 induce increased aromatase expression and as a consequence increased estrogen production in breast CAFs, effects abolished by knockdown of GPER [102]. Similar observations by others suggest such mechanisms may contribute to clinically-observed tamoxifen resistance [74]. Additionally, increased local estrogen levels could promote the growth of primary ER $\alpha$-positive breast tumors, thus driving tumor progression.

\section{GPER in the Immune System}

Stromal cells in the tumor microenvironment also include a wide variety of immune cells, which play a role not only in elimination of cancer cells, but also promoting tumor formation and progression $[110,111]$. For example, tumor-associated macrophages contribute to tumor progression and metastasis by secreting multiple growth factors and inflammatory cytokines into the tumor microenvironment $[112,113]$. Estrogens display multiple effects on the immune system, including both development and function [114-116]. ER $\alpha$, ER $\beta$, and GPER knockout (KO) mouse studies revealed that ER $\alpha$ mediates an early developmental blockage of thymocytes, whereas GPER is required for apoptosis of T cell double-positive thymocytes [117]. The latter observation could be mimicked by systemic in vivo treatment with the GPER-selective agonist, G-1, which induced thymic atrophy and thymocyte apoptosis in mice, while not altering the early developmental blockage of thymocytes mediated by ER. GPER deficiency also leads to a lower frequency of T cells, specifically CD62L-expressing T cells, in both male and female mice, suggesting that GPER deficiency impairs production of T cells in the thymus [118]. An anti-inflammatory role for GPER is further supported by G-1's ability to expand regulatory T cell populations [119] and induce secretion of the anti-inflammatory cytokine, IL-10, from Th17 polarized cells [120]. 
Estrogens have been gaining more interest as potential anti-inflammatory therapeutic agents for autoimmune diseases, in particular multiple sclerosis (MS) [121]. In the experimental autoimmune encephalomyelitis (EAE) mouse model of MS, estrogen and G-1 provide a protective role against the disease by enhancing the suppressive activity of $\mathrm{CD}^{+}{ }^{+} \mathrm{Foxp}^{+}{ }^{+} \mathrm{T}$ regulatory cells, through a GPER- and PD-1-dependent pathway [122]. G-1 provides further benefit in the EAE model by decreasing the levels of pro-inflammatory cytokines, such as IFN- $\gamma$ and IL-17, in immune cells isolated from EAE mice [123]. In murine models of diet-induced atherosclerosis, a disease driven by inflammation and the generation of foam cells from macrophages, GPER-deficient mice exhibited increased aortic lesions and inflammation, whereas treatment of atherosclerotic wild-type mice with G-1 reduced macrophage infiltration and lesion extent [124]. In a contemporaneous report to this review, activation of GPER during pregnancy appears both necessary and sufficient to suppress IFN signaling, particularly in reproductive and fetal tissues, such that inactivation or inhibition of GPER in mice prevented fetal development and promoted fetal demise, specifically in the context of viral infection and maternal inflammation [125]. Thus, GPER could prove to be a valuable anti-inflammatory target in chronic inflammatory diseases, including multiple sclerosis and Crohn's disease/ulcerative colitis [126], as well as acute inflammation during viral infections.

GPER also plays a critical role in metabolic regulation via modulation of inflammatory pathways as demonstrated by both murine models and epidemiological data $[25,27]$. GPER $\mathrm{KO}$ mice display higher levels of systemic pro-inflammatory cytokines, such as IL- $1 \beta$, IL-6, monocyte chemoattractant protein-1 (MCP-1), serum amyloid A 3 (SAA3), and tumor necrosis factor- $\alpha$ (TNF- $\alpha$ ), suggesting an anti-inflammatory role for the receptor [24,127]. In a mouse model of metabolic dysfunction and inflammation, treatment of ovariectomized (OVX) mice with G-1 resulted in decreased plasma levels of TNF- $\alpha$, MCP-1, IL-6, leptin, and resistin, representing a reduced inflammatory state [25]. Furthermore, G-1 treatment resulted in decreased expression of inflammatory genes in metabolic tissues. In vitro, estrogen decreases the expression of pro-inflammatory genes in (pre)adipocytes, even following ER $\alpha$ knockdown, suggesting the presence of an ER $\alpha$-independent mechanism, possibly involving GPER [128]. Collectively, these reports support an anti-inflammatory role for GPER in multiple settings, suggesting a possible role in other (patho)physiological settings including cancer, where both systemic and local (microenvironment) inflammation play important roles in carcinogenesis (Figure 1) [129].

\section{GPER in Adipose/Adipocytes: Obesity and Influence on Cancer Development}

In addition to fibroblasts and immune cells, the tumor microenvironment also contains adipocytes, which can be greatly enriched in fat-rich breast tissue [130,131]. Adipose tissue is no longer considered an inert energy storage component but is emerging as an active tissue involved in the secretion of various hormones and cytokines (adipokines) and the regulation of fuel availability, which together can play a key role in cancer development and progression (Figure 1) [131,132]. Adipose tissue and adipocytes are an integral part of both normal and tumor breast tissue along with immune cells, soluble factors, and the extracellular matrix. Evidence suggests extensive cross-talk between breast cancer cells and local adipocytes, as well as fat depots throughout the body, with obesity promoting breast cancer development in the post-menopausal woman [133]. Obesity leads to a chronic state of inflammation and persistent stress in white adipose tissue (WAT) that enhances carcinogenesis [132]. Furthermore, tumor growth and aggressiveness are enhanced by obesity due to the increased availability of fatty acids and other metabolites from adipocytes, aberrant adipokine signaling patterns, and associated immune dysfunction [131,134,135]. Mature adipocytes provide adipokines and lipids to cancer cells, whereas stromal and immune cells from adipose tissue infiltrate carcinomas to promote a pro-tumorigenic microenvironment [133].

GPER plays an important role in body weight regulation through fat deposition and accumulation. GPER-deficient mice exhibit increased overall body fat [24], whereas in diet- 
induced obese (DIO) and OVX mice, activation of GPER by its agonist G-1 results in reduced adiposity [25]. G-1 also promoted the expression of genes involved in mitochondrial biogenesis and fatty acid oxidation in WAT, suggesting a change in fuel utilization [25]. In 3T3-L1 cells, estrogen attenuates the adverse effects of inflammation on mitochondrial function by activating the protein kinase A pathway through GPER [136]. Furthermore, treatment of 3T3-L1 preadipocytes with estrogen or G-1 during differentiation inhibited lipid accumulation in adipocytes through the perturbation of mitotic clonal expansion, which was reversed by GPER knockdown [137].

Carcinogenesis is a highly complex multi-stage process in which GPER may exhibit multiple important roles. Based on the current understanding of the field, GPER could influence cancer development through both direct and/or indirect effects on WAT. GPER activation can exert differential effects on multiple cell types in breast tumors, promoting an anti-inflammatory phenotype and the oxidation of fatty acids [137]. The resulting smaller adipocytes, with reduced adipokine production, could possibly limit the availability of lipids and nutrients to breast tumors and inhibit their growth. Lastly, treatment with G-1 improves insulin sensitivity and lowers fasting plasma glucose and insulin levels in DIO and OVX mice [25]. An association between plasma insulin/IGF-1 concentrations and tumor development is widely acknowledged [138]. Thus, GPER activation may lower the plasma concentrations of insulin, thereby lowering the risk of cancer development. Therefore, GPER may regulate tumor progression by altering various functions in metabolic tissues.

\section{Therapeutic Potential of Targeting GPER}

Over the past several years, increasing evidence suggests that GPER could serve as a potential target for therapeutic intervention in several diseases. In the ER $\alpha$-positive breast cancer setting, the cross-activation of GPER by the clinically widely used, ER $\alpha$ targeted drug tamoxifen is hypothesized to contribute to the development of tamoxifenresistant relapse tumors $[17,18]$. Combinatorial treatment of tamoxifen and the GPER inhibitor, G15, "re-sensitizes" tamoxifen-resistant tumors to tamoxifen [17]. To this end, the GPER-selective antagonists, G15 or G36 could potentially prove beneficial as part of a combinatorial therapy, with tamoxifen, for ER $\alpha$-positive (relapse) breast cancer patients. Aside from GPER-inhibiting combinatorial therapies, an $\operatorname{ER} \alpha$ antagonist that also inhibits GPER could prove beneficial for this class of breast cancer patient. To date, one study has identified the only known compound, termed MIBE, that exhibits such dual antagonist activity (i.e., antagonism of both ER $\alpha$ and GPER) [53]. Unfortunately, this compound shows poor binding affinity for $\mathrm{ER} \alpha\left(\mathrm{IC}_{50}>10 \mu \mathrm{M}\right)$, making it a poor candidate for clinical development. Nevertheless, MIBE could serve as a foundation for future ER $\alpha /$ GPER dual antagonists. Aside from pharmacological inhibition of GPER, inhibiting ER $\alpha$ in the absence of cross-activating GPER, could also be a viable pharmacological option for the treatment of ER $\alpha$-positive breast cancers [64]. Such a compound could delay the development of ER $\alpha$ positive relapse tumors. ER $\alpha$-targeted antagonists that harbor such a molecular profile (i.e., high selectivity towards ER $\alpha$ with no selectivity towards GPER) have yet to be reported, but the identification of the ER $\alpha$-selective/GPER non-selective agonist, AB-1, demonstrates that such molecular selectivity is achievable [56].

Whereas inhibition of GPER (or lack of GPER cross-activation) has possible therapeutic value for treating ER $\alpha$-positive breast cancers, activation of the receptor could prove beneficial in the treatment of triple-negative breast cancers (TNBCs). G-1-mediated activation of GPER, in TNBC cell lines, results in cell cycle arrest and apoptosis, suggesting a protective role for GPER in TNBCs [139,140]. G-1 also inhibits tumor growth in xenograft models of TNBC, further supporting a case for GPER as a target in TNBC [23]. Although activation of GPER, in TNBC, appears beneficial [141,142], the field is still divided on whether GPER promotes or inhibits TNBC growth due to contradictory findings that show a pro-tumorigenic role for GPER in TNBC $[143,144]$. Nevertheless, given the lack of targeted therapies for TNBC, GPER-targeted therapies (agonists or antagonists) warrant further exploration. 
GPER-targeted therapy has also garnered interest in the field of melanoma, with the demonstration that a combinatorial treatment of anti-PD-1 and G-1 increased the efficacy of the anti-PD-1 monotherapy in a murine model of melanoma, resulting in significantly smaller melanoma tumors and increased survival of the mice [22]. This discovery has led to the initiation of the first G-1 Phase I clinical trial (NCT04130516) by Linnaeus Therapeutics Inc. with the hope of advancing this drug to further clinical testing as a potential therapy for the treatment of melanoma and other cancers.

Therapeutic targeting of GPER may also be beneficial in metabolic dysfunction, such as obesity and diabetes. Selective activation of GPER by G-1, in murine models of obesity and metabolic dysfunction, exerts beneficial effects and mitigates obesity and diabetes. Mice exhibited reduced adiposity, inflammation, fasting glucose, insulin and cholesterol levels, with improved insulin sensitivity [25]. Despite G-1 mimicking a majority of the beneficial metabolic effects of E2, it lacks the classical feminizing effects of E2, as assessed by uterine imbibition. These results indicate that G-1 could be a drug of choice for metabolic dysfunction in males as well. Overall, GPER agonists exert multiple and differential effects in numerous tissues to regulate body weight and maintain metabolic homeostasis. These effects may have favorable outcomes in terms of tumor development and progression due to reduced substrate availability and blunted insulin signaling and inflammation. Thus, GPER-selective agonists may represent potential therapeutic candidate drugs for the treatment of obesity, diabetes, and certain cancers.

\section{Conclusions}

Estrogens play critical roles in both health and disease. Therapeutic regulation of its non-classical estrogen receptor GPER harbors potential clinical benefits in treating diseases in various tissue types, including adipose, skin, breast, and liver. However, the benefits of therapeutic activation or inhibition of GPER have been questioned in certain tissue types, specifically breast tissue, in the case of TNBCs, where some data support a proliferative effect of GPER activation. Nevertheless, data have shown therapeutic benefits of the GPER-selective agonist G-1 in multiple disease models, ranging from multiple sclerosis to atherosclerosis to melanoma and pancreatic cancer, to diabetes and obesity. With the initiation of the first Phase I clinical trial of G-1, the prospects for clinical targeting of GPER are promising and only time and additional research will tell if this approach will have a positive impact on human disease.

Author Contributions: R.A.P., G.S. and E.R.P. wrote and edited the manuscript. All authors have read and agreed to the published version of the manuscript.

Funding: E.R.P. is supported by grants from the National Institutes of Health (NIH R01 CA163890 and CA194496) and Dialysis Clinic, Inc., the Autophagy, Inflammation and Metabolism (AIM) Center of Biomedical Research Excellence (NIH P20 GM121176) and by the UNM Comprehensive Cancer Center (NIH grant P30 CA118100).

Acknowledgments: Figures created with Biorender.com (accessed on 08/03/2021).

Conflicts of Interest: E.R.P. is an inventor on U.S. Patent Nos. 7,875,721 and 8,487,100 for GPERselective ligands and imaging agents and U.S. Patent Nos. 10,251,870;10,471,047; 10,561,648 and 10,682,341 for applications of GPER-selective ligands.

\section{References}

1. Nilsson, S.; Makela, S.; Treuter, E.; Tujague, M.; Thomsen, J.; Andersson, G.; Enmark, E.; Pettersson, K.; Warner, M.; Gustafsson, J.A. Mechanisms of estrogen action. Physiol. Rev. 2001, 81, 1535-1565. [CrossRef]

2. Prossnitz, E.R.; Barton, M. The G-protein-coupled estrogen receptor GPER in health and disease. Nat. Rev. Endocrinol. 2011, 7, 715-726. [CrossRef]

3. Lombardi, G.; Zarrilli, S.; Colao, A.; Paesano, L.; Di Somma, C.; Rossi, F.; De Rosa, M. Estrogens and health in males. Mol. Cell. Endocrinol. 2001, 178, 51-55. [CrossRef]

4. Somasundaram, A.; Rothenberger, N.J.; Stabile, L.P. The Impact of Estrogen in the Tumor Microenvironment. Adv. Exp. Med. Biol. 2020, 1277, 33-52. [CrossRef] 
5. Jensen, E.V.; DeSombre, E.R. Estrogen-receptor interaction. Science 1973, 182, 126-134. [CrossRef]

6. Kuiper, G.G.; Enmark, E.; Pelto-Huikko, M.; Nilsson, S.; Gustafsson, J.A. Cloning of a novel receptor expressed in rat prostate and ovary. Proc. Natl. Acad. Sci. USA 1996, 93, 5925-5930. [CrossRef] [PubMed]

7. Revankar, C.M.; Cimino, D.F.; Sklar, L.A.; Arterburn, J.B.; Prossnitz, E.R. A transmembrane intracellular estrogen receptor mediates rapid cell signaling. Science 2005, 307, 1625-1630. [CrossRef] [PubMed]

8. Russo, J.; Russo, I.H. The role of estrogen in the initiation of breast cancer. J. Steroid Biochem. Mol. Biol. 2006, 102, 89-96. [CrossRef]

9. Ariazi, E.A.; Ariazi, J.L.; Cordera, F.; Jordan, V.C. Estrogen receptors as therapeutic targets in breast cancer. Curr. Top. Med. Chem. 2006, 6, 181-202. [CrossRef] [PubMed]

10. Early Breast Cancer Trialists' Collaborative Group (EBCTCG). Effects of chemotherapy and hormonal therapy for early breast cancer on recurrence and 15-year survival: An overview of the randomised trials. Lancet 2005, 365, 1687-1717. [CrossRef]

11. De Savi, C.; Bradbury, R.H.; Rabow, A.A.; Norman, R.A.; de Almeida, C.; Andrews, D.M.; Ballard, P.; Buttar, D.; Callis, R.J.; Currie, G.S.; et al. Optimization of a Novel Binding Motif to (E)-3-(3,5-Difluoro-4-((1R,3R)-2-(2-fluoro-2-methylpropyl)-3-methyl-2,3,4,9tetra hydro-1H-pyrido [3,4-b]indol-1-yl)phenyl)acrylic Acid (AZD9496), a Potent and Orally Bioavailable Selective Estrogen Receptor Downregulator and Antagonist. J. Med. Chem. 2015, 58, 8128-8140. [CrossRef]

12. Wardell, S.E.; Yllanes, A.P.; Baker, J.G.; Baldi, R.M.; Krebs, T.K.; Sorrentino, J.; Bisi, J.; Strum, J.; Norris, J.D. Abstract 5641: Effects of G1T48, a novel orally bioavailable selective estrogen receptor degrader (SERD), and the CDK4/6 inhibitor, G1T38, on tumor growth in animal models of endocrine resistant breast cancer. Cancer Res. 2017, 77, 5641. [CrossRef]

13. Dickler, M.; Villanueva, R.; Perez Fidalgo, J.; Mayer, I.; Boni, V.; Winer, E.; Hamilton, E.; Bellet, M.; Urruticoechea, A.; GonzalezMartin, A.; et al. Abstract PD5-10: A first-in-human phase I study to evaluate the oral selective estrogen receptor degrader (SERD), GDC-0927, in postmenopausal women with estrogen receptor positive (ER+) HER2-negative metastatic breast cancer (BC). Cancer Res. 2018, 78, PD5-10. [CrossRef]

14. Shomali, M.; Cheng, J.; Koundinya, M.; Weinstein, M.; Malkova, N.; Sun, F.; Hebert, A.; Cindachao, M.; Hoffman, D.; McManus, J.; et al. Abstract P3-04-05: Identification of SAR439859, an orally bioavailable selective estrogen receptor degrader (SERD) that has strong antitumor activity in wild-type and mutant ER+ breast cancer models. Cancer Res. 2017, 77, P3-04-05. [CrossRef]

15. Juric, D.; Curigliano, G.; Cresta, S.; Yap, Y.-S.; Terret, C.; Duhoux, F.; Takahashi, S.; Kundamal, N.; Bhansali, S.; Liao, S.; et al. Abstract P5-21-04: Phase I/Ib study of the SERD LSZ102 alone or in combination with ribociclib in ER+ breast cancer. Cancer Res. 2018, 78, P5-21-04. [CrossRef]

16. Bardia, A.; Aftimos, P.; Bihani, T.; Anderson-Villaluz, A.T.; Jung, J.; Conlan, M.G.; Kaklamani, V.G. EMERALD: Phase III trial of elacestrant (RAD1901) vs. endocrine therapy for previously treated ER+ advanced breast cancer. Future Oncol. 2019, 15, 3209-3218. [CrossRef]

17. Mo, Z.; Liu, M.; Yang, F.; Luo, H.; Li, Z.; Tu, G.; Yang, G. GPR30 as an initiator of tamoxifen resistance in hormone-dependent breast cancer. Breast Cancer Res. 2013, 15, R114. [CrossRef] [PubMed]

18. Ignatov, A.; Ignatov, T.; Roessner, A.; Costa, S.D.; Kalinski, T. Role of GPR30 in the mechanisms of tamoxifen resistance in breast cancer MCF-7 cells. Breast Cancer Res. Treat. 2010, 123, 87-96. [CrossRef] [PubMed]

19. Prossnitz, E.R.; Arterburn, J.B. International Union of Basic and Clinical Pharmacology. XCVII. G Protein-Coupled Estrogen Receptor and Its Pharmacologic Modulators. Pharmacol. Rev. 2015, 67, 505-540. [CrossRef] [PubMed]

20. Petrie, W.K.; Dennis, M.K.; Hu, C.; Dai, D.; Arterburn, J.B.; Smith, H.O.; Hathaway, H.J.; Prossnitz, E.R. G protein-coupled estrogen receptor-selective ligands modulate endometrial tumor growth. Obstet. Gynecol. Int. 2013, 2013, 472720. [CrossRef]

21. Jacenik, D.; Cygankiewicz, A.I.; Krajewska, W.M. The G protein-coupled estrogen receptor as a modulator of neoplastic transformation. Mol. Cell. Endocrinol. 2016, 429, 10-18. [CrossRef]

22. Natale, C.A.; Li, J.; Zhang, J.; Dahal, A.; Dentchev, T.; Stanger, B.Z.; Ridky, T.W. Activation of G protein-coupled estrogen receptor signaling inhibits melanoma and improves response to immune checkpoint blockade. eLife 2018, 7. [CrossRef]

23. Wei, W.; Chen, Z.J.; Zhang, K.S.; Yang, X.L.; Wu, Y.M.; Chen, X.H.; Huang, H.B.; Liu, H.L.; Cai, S.H.; Du, J.; et al. The activation of G protein-coupled receptor 30 (GPR30) inhibits proliferation of estrogen receptor-negative breast cancer cells in vitro and in vivo. Cell Death Dis. 2014, 5, e1428. [CrossRef]

24. Sharma, G.; Hu, C.; Brigman, J.L.; Zhu, G.; Hathaway, H.J.; Prossnitz, E.R. GPER deficiency in male mice results in insulin resistance, dyslipidemia, and a proinflammatory state. Endocrinology 2013, 154, 4136-4145. [CrossRef]

25. Sharma, G.; Hu, C.; Staquicini, D.I.; Brigman, J.L.; Liu, M.; Mauvais-Jarvis, F.; Pasqualini, R.; Arap, W.; Arterburn, J.B.; Hathaway, H.J.; et al. Preclinical efficacy of the GPER-selective agonist G-1 in mouse models of obesity and diabetes. Sci. Transl. Med. 2020 12. [CrossRef] [PubMed]

26. Sharma, G.; Prossnitz, E.R. GPER/GPR30 Knockout Mice: Effects of GPER on Metabolism. Methods Mol. Biol. 2016, 1366, 489-502. [CrossRef] [PubMed]

27. Sharma, G.; Prossnitz, E.R. G-Protein-Coupled Estrogen Receptor (GPER) and Sex-Specific Metabolic Homeostasis. Adv. Exp. Med. Biol. 2017, 1043, 427-453. [CrossRef] [PubMed]

28. Sharma, G.; Mauvais-Jarvis, F.; Prossnitz, E.R. Roles of G protein-coupled estrogen receptor GPER in metabolic regulation. J. Steroid Biochem. Mol. Biol. 2018, 176, 31-37. [CrossRef]

29. Perry, R.J.; Shulman, G.I. Mechanistic Links between Obesity, Insulin, and Cancer. Trends Cancer 2020, 6, 75-78. [CrossRef]

30. King, W.J.; Greene, G.L. Monoclonal antibodies localize oestrogen receptor in the nuclei of target cells. Nature 1984, 307, 745-747. [CrossRef] 
31. Heldring, N.; Pike, A.; Andersson, S.; Matthews, J.; Cheng, G.; Hartman, J.; Tujague, M.; Strom, A.; Treuter, E.; Warner, M.; et al. Estrogen receptors: How do they signal and what are their targets. Physiol. Rev. 2007, 87, 905-931. [CrossRef]

32. Dahlman-Wright, K.; Cavailles, V.; Fuqua, S.A.; Jordan, V.C.; Katzenellenbogen, J.A.; Korach, K.S.; Maggi, A.; Muramatsu, M.; Parker, M.G.; Gustafsson, J.A. International Union of Pharmacology. LXIV. Estrogen receptors. Pharmacol. Rev. 2006, 58, 773-781. [CrossRef]

33. Ruggiero, R.J.; Likis, F.E. Estrogen: Physiology, pharmacology, and formulations for replacement therapy. J. Midwifery Womens Health 2002, 47, 130-138. [CrossRef]

34. Nilsson, S.; Gustafsson, J.A. Estrogen receptors: Therapies targeted to receptor subtypes. Clin. Pharmacol. Ther. 2011, 89, 44-55. [CrossRef]

35. Frasor, J.; Stossi, F.; Danes, J.M.; Komm, B.; Lyttle, C.R.; Katzenellenbogen, B.S. Selective estrogen receptor modulators: Discrimination of agonistic versus antagonistic activities by gene expression profiling in breast cancer cells. Cancer Res. 2004, 64, 1522-1533. [CrossRef]

36. Bologa, C.G.; Revankar, C.M.; Young, S.M.; Edwards, B.S.; Arterburn, J.B.; Kiselyov, A.S.; Parker, M.A.; Tkachenko, S.E.; Savchuck, N.P.; Sklar, L.A.; et al. Virtual and biomolecular screening converge on a selective agonist for GPR30. Nat. Chem. Biol. 2006, 2, 207-212. [CrossRef]

37. Banerjee, S.; Chambliss, K.L.; Mineo, C.; Shaul, P.W. Recent insights into non-nuclear actions of estrogen receptor alpha. Steroids 2014, 81, 64-69. [CrossRef]

38. Chambliss, K.L.; Wu, Q.; Oltmann, S.; Konaniah, E.S.; Umetani, M.; Korach, K.S.; Thomas, G.D.; Mineo, C.; Yuhanna, I.S.; Kim, S.H.; et al. Non-nuclear estrogen receptor alpha signaling promotes cardiovascular protection but not uterine or breast cancer growth in mice. J. Clin. Investig. 2010, 120, 2319-2330. [CrossRef]

39. Levin, E.R. Extranuclear steroid receptors are essential for steroid hormone actions. Annu. Rev. Med. 2015, 66, 271-280. [CrossRef]

40. Prossnitz, E.R.; Maggiolini, M. Mechanisms of estrogen signaling and gene expression via GPR30. Mol. Cell. Endocrinol. 2009, 308, 32-38. [CrossRef]

41. Filardo, E.J.; Quinn, J.A.; Bland, K.I.; Frackelton, A.R., Jr. Estrogen-induced activation of Erk-1 and Erk-2 requires the G proteincoupled receptor homolog, GPR30, and occurs via trans-activation of the epidermal growth factor receptor through release of HB-EGF. Mol. Endocrinol. 2000, 14, 1649-1660. [CrossRef]

42. Carmeci, C.; Thompson, D.A.; Ring, H.Z.; Francke, U.; Weigel, R.J. Identification of a gene (GPR30) with homology to the G-protein-coupled receptor superfamily associated with estrogen receptor expression in breast cancer. Genomics 1997, 45, 607-617. [CrossRef] [PubMed]

43. Owman, C.; Blay, P.; Nilsson, C.; Lolait, S.J. Cloning of human cDNA encoding a novel heptahelix receptor expressed in Burkitt's lymphoma and widely distributed in brain and peripheral tissues. Biochem. Biophys. Res. Commun. 1996, 228, 285-292. [CrossRef]

44. Wang, Z. Transactivation of Epidermal Growth Factor Receptor by G Protein-Coupled Receptors: Recent Progress, Challenges and Future Research. Int. J. Mol. Sci. 2016, 17, 95. [CrossRef] [PubMed]

45. Gschwind, A.; Zwick, E.; Prenzel, N.; Leserer, M.; Ullrich, A. Cell communication networks: Epidermal growth factor receptor transactivation as the paradigm for interreceptor signal transmission. Oncogene 2001, 20, 1594-1600. [CrossRef] [PubMed]

46. Daub, H.; Weiss, F.U.; Wallasch, C.; Ullrich, A. Role of transactivation of the EGF receptor in signalling by G-protein-coupled receptors. Nature 1996, 379, 557-560. [CrossRef]

47. Filardo, E.; Quinn, J.; Pang, Y.; Graeber, C.; Shaw, S.; Dong, J.; Thomas, P. Activation of the novel estrogen receptor G proteincoupled receptor 30 (GPR30) at the plasma membrane. Endocrinology 2007, 148, 3236-3245. [CrossRef]

48. Pupo, M.; Vivacqua, A.; Perrotta, I.; Pisano, A.; Aquila, S.; Abonante, S.; Gasperi-Campani, A.; Pezzi, V.; Maggiolini, M. The nuclear localization signal is required for nuclear GPER translocation and function in breast Cancer-Associated Fibroblasts (CAFs). Mol. Cell. Endocrinol. 2013, 376, 23-32. [CrossRef]

49. Pupo, M.; Bodmer, A.; Berto, M.; Maggiolini, M.; Dietrich, P.Y.; Picard, D. A genetic polymorphism repurposes the G-protein coupled and membrane-associated estrogen receptor GPER to a transcription factor-like molecule promoting paracrine signaling between stroma and breast carcinoma cells. Oncotarget 2017, 8, 46728-46744. [CrossRef]

50. Madeo, A.; Maggiolini, M. Nuclear alternate estrogen receptor GPR30 mediates 17beta-estradiol-induced gene expression and migration in breast cancer-associated fibroblasts. Cancer Res. 2010, 70, 6036-6046. [CrossRef]

51. Vivacqua, A.; Bonofiglio, D.; Albanito, L.; Madeo, A.; Rago, V.; Carpino, A.; Musti, A.M.; Picard, D.; Ando, S.; Maggiolini, M. 17beta-estradiol, genistein, and 4-hydroxytamoxifen induce the proliferation of thyroid cancer cells through the $\mathrm{g}$ protein-coupled receptor GPR30. Mol. Pharmacol. 2006, 70, 1414-1423. [CrossRef]

52. Vivacqua, A.; Bonofiglio, D.; Recchia, A.G.; Musti, A.M.; Picard, D.; Ando, S.; Maggiolini, M. The G protein-coupled receptor GPR30 mediates the proliferative effects induced by 17 beta-estradiol and hydroxytamoxifen in endometrial cancer cells. Mol. Endocrinol. 2006, 20, 631-646. [CrossRef]

53. Lappano, R.; Santolla, M.F.; Pupo, M.; Sinicropi, M.S.; Caruso, A.; Rosano, C.; Maggiolini, M. MIBE acts as antagonist ligand of both estrogen receptor alpha and GPER in breast cancer cells. Breast Cancer Res. 2012, 14, R12. [CrossRef] [PubMed]

54. Stauffer, S.R.; Coletta, C.J.; Tedesco, R.; Nishiguchi, G.; Carlson, K.; Sun, J.; Katzenellenbogen, B.S.; Katzenellenbogen, J.A. Pyrazole ligands: Structure-affinity/activity relationships and estrogen receptor-alpha-selective agonists. J. Med. Chem. 2000, 43, 4934-4947. [CrossRef] 
55. Meyers, M.J.; Sun, J.; Carlson, K.E.; Marriner, G.A.; Katzenellenbogen, B.S.; Katzenellenbogen, J.A. Estrogen receptor-beta potency-selective ligands: Structure-activity relationship studies of diarylpropionitriles and their acetylene and polar analogues. J. Med. Chem. 2001, 44, 4230-4251. [CrossRef] [PubMed]

56. Revankar, C.M.; Bologa, C.G.; Pepermans, R.A.; Sharma, G.; Petrie, W.K.; Alcon, S.N.; Field, A.S.; Ramesh, C.; Parker, M.A.; Savchuk, N.P.; et al. A Selective Ligand for Estrogen Receptor Proteins Discriminates Rapid and Genomic Signaling. Cell Chem. Biol. 2019, 26, 1692-1702.e5. [CrossRef] [PubMed]

57. Dennis, M.K.; Burai, R.; Ramesh, C.; Petrie, W.K.; Alcon, S.N.; Nayak, T.K.; Bologa, C.G.; Leitao, A.; Brailoiu, E.; Deliu, E.; et al. In vivo effects of a GPR30 antagonist. Nat. Chem. Biol. 2009, 5, 421-427. [CrossRef]

58. Dennis, M.K.; Field, A.S.; Burai, R.; Ramesh, C.; Petrie, W.K.; Bologa, C.G.; Oprea, T.I.; Yamaguchi, Y.; Hayashi, S.; Sklar, L.A.; et al. Identification of a GPER/GPR30 antagonist with improved estrogen receptor counterselectivity. J. Steroid Biochem. Mol. Biol. 2011, 127, 358-366. [CrossRef] [PubMed]

59. Lappano, R.; Rosano, C.; Santolla, M.F.; Pupo, M.; De Francesco, E.M.; De Marco, P.; Ponassi, M.; Spallarossa, A.; Ranise, A.; Maggiolini, M. Two novel GPER agonists induce gene expression changes and growth effects in cancer cells. Curr. Cancer Drug Targets 2012, 12, 531-542. [CrossRef]

60. O'Dea, A.; Sondergard, C.; Sweeney, P.; Arnatt, C.K. A Series of Indole-Thiazole Derivatives Act as GPER Agonists and Inhibit Breast Cancer Cell Growth. ACS Med. Chem. Lett. 2018, 9, 901-906. [CrossRef]

61. Ma, C.X.; Sanchez, C.G.; Ellis, M.J. Predicting endocrine therapy responsiveness in breast cancer. Oncology 2009, $23,133-142$.

62. Musgrove, E.A.; Sutherland, R.L. Biological determinants of endocrine resistance in breast cancer. Nat. Rev. Cancer 2009, 9, 631-643. [CrossRef]

63. Ma, C.X.; Reinert, T.; Chmielewska, I.; Ellis, M.J. Mechanisms of aromatase inhibitor resistance. Nat. Rev. Cancer 2015, 15, 261-275. [CrossRef] [PubMed]

64. Pepermans, R.A.; Prossnitz, E.R. ERalpha-targeted endocrine therapy, resistance and the role of GPER. Steroids 2019, $152,108493$. [CrossRef]

65. Jeselsohn, R.; Buchwalter, G.; De Angelis, C.; Brown, M.; Schiff, R. ESR1 mutations-a mechanism for acquired endocrine resistance in breast cancer. Nat. Rev. Clin. Oncol. 2015, 12, 573-583. [CrossRef] [PubMed]

66. Ignatov, A.; Ignatov, T.; Weissenborn, C.; Eggemann, H.; Bischoff, J.; Semczuk, A.; Roessner, A.; Costa, S.D.; Kalinski, T. G-proteincoupled estrogen receptor GPR30 and tamoxifen resistance in breast cancer. Breast Cancer Res. Treat. 2011, 128, 457-466. [CrossRef] [PubMed]

67. Filardo, E.J.; Graeber, C.T.; Quinn, J.A.; Resnick, M.B.; Giri, D.; DeLellis, R.A.; Steinhoff, M.M.; Sabo, E. Distribution of GPR30, a seven membrane-spanning estrogen receptor, in primary breast cancer and its association with clinicopathologic determinants of tumor progression. Clin. Cancer Res. 2006, 12, 6359-6366. [CrossRef]

68. Marjon, N.A.; Hu, C.; Hathaway, H.J.; Prossnitz, E.R. G protein-coupled estrogen receptor regulates mammary tumorigenesis and metastasis. Mol. Cancer Res. 2014, 12, 1644-1654. [CrossRef]

69. Ignatov, T.; Claus, M.; Nass, N.; Haybaeck, J.; Seifert, B.; Kalinski, T.; Ortmann, O.; Ignatov, A. G-protein-coupled estrogen receptor GPER-1 expression in hormone receptor-positive breast cancer is associated with poor benefit of tamoxifen. Breast Cancer Res. Treat. 2018. [CrossRef]

70. Ignatov, T.; Treeck, O.; Kalinski, T.; Ortmann, O.; Ignatov, A. GPER-1 expression is associated with a decreased response rate to primary tamoxifen therapy of breast cancer patients. Arch. Gynecol. Obstet. 2020, 301, 565-571. [CrossRef]

71. Zhang, L.; Li, Y.; Lan, L.; Liu, R.; Wu, Y.; Qu, Q.; Wen, K. Tamoxifen has a proliferative effect in endometrial carcinoma mediated via the GPER/EGFR/ERK/cyclin D1 pathway: A retrospective study and an in vitro study. Mol. Cell. Endocrinol. 2016, 437, 51-61. [CrossRef] [PubMed]

72. Thomas, P.; Pang, Y.; Filardo, E.J.; Dong, J. Identity of an estrogen membrane receptor coupled to a G protein in human breast cancer cells. Endocrinology 2005, 146, 624-632. [CrossRef]

73. Li, Y.; Chen, Y.; Zhu, Z.X.; Liu, X.H.; Yang, L.; Wan, L.; Lei, T.W.; Wang, X.D. 4-Hydroxytamoxifen-stimulated processing of cyclin $\mathrm{E}$ is mediated via $\mathrm{G}$ protein-coupled receptor 30 (GPR30) and accompanied by enhanced migration in MCF-7 breast cancer cells. Toxicology 2013, 309, 61-65. [CrossRef] [PubMed]

74. Catalano, S.; Giordano, C.; Panza, S.; Chemi, F.; Bonofiglio, D.; Lanzino, M.; Rizza, P.; Romeo, F.; Fuqua, S.A.; Maggiolini, M.; et al. Tamoxifen through GPER upregulates aromatase expression: A novel mechanism sustaining tamoxifen-resistant breast cancer cell growth. Breast Cancer Res. Treat. 2014, 146, 273-285. [CrossRef] [PubMed]

75. Joosse, A.; Collette, S.; Suciu, S.; Nijsten, T.; Patel, P.M.; Keilholz, U.; Eggermont, A.M.; Coebergh, J.W.; de Vries, E. Sex is an independent prognostic indicator for survival and relapse/progression-free survival in metastasized stage III to IV melanoma: A pooled analysis of five European organisation for research and treatment of cancer randomized controlled trials. J. Clin. Oncol. 2013, 31, 2337-2346. [CrossRef]

76. Cook, M.B.; McGlynn, K.A.; Devesa, S.S.; Freedman, N.D.; Anderson, W.F. Sex disparities in cancer mortality and survival. Cancer Epidemiol. Biomarkers Prev. 2011, 20, 1629-1637. [CrossRef]

77. Nicolaidou, E.; Katsambas, A.D. Pigmentation disorders: Hyperpigmentation and hypopigmentation. Clin. Dermatol. 2014, 32, 66-72. [CrossRef] 
78. Sun, M.; Xie, H.F.; Tang, Y.; Lin, S.Q.; Li, J.M.; Sun, S.N.; Hu, X.L.; Huang, Y.X.; Shi, W.; Jian, D. G protein-coupled estrogen receptor enhances melanogenesis via cAMP-protein kinase (PKA) by upregulating microphthalmia-related transcription factor-tyrosinase in melanoma. J. Steroid Biochem. Mol. Biol. 2017, 165, 236-246. [CrossRef]

79. Natale, C.A.; Duperret, E.K.; Zhang, J.; Sadeghi, R.; Dahal, A.; O’Brien, K.T.; Cookson, R.; Winkler, J.D.; Ridky, T.W. Sex steroids regulate skin pigmentation through nonclassical membrane-bound receptors. eLife 2016, 5. [CrossRef]

80. Cocconi, G.; Bella, M.; Calabresi, F.; Tonato, M.; Canaletti, R.; Boni, C.; Buzzi, F.; Ceci, G.; Corgna, E.; Costa, P.; et al. Treatment of metastatic malignant melanoma with dacarbazine plus tamoxifen. N. Engl. J. Med. 1992, 327, 516-523. [CrossRef]

81. Beguerie, J.R.; Xingzhong, J.; Valdez, R.P. Tamoxifen vs. non-tamoxifen treatment for advanced melanoma: A meta-analysis. Int. J. Dermatol. 2010, 49, 1194-1202. [CrossRef] [PubMed]

82. Kanter-Lewensohn, L.; Girnita, L.; Girnita, A.; Dricu, A.; Olsson, G.; Leech, L.; Nilsson, G.; Hilding, A.; Wejde, J.; Brismar, K.; et al. Tamoxifen-induced cell death in malignant melanoma cells: Possible involvement of the insulin-like growth factor-1 (IGF-1) pathway. Mol. Cell. Endocrinol. 2000, 165, 131-137. [CrossRef]

83. Piantelli, M.; Maggiano, N.; Ricci, R.; Larocca, L.M.; Capelli, A.; Scambia, G.; Isola, G.; Natali, P.G.; Ranelletti, F.O. Tamoxifen and quercetin interact with type II estrogen binding sites and inhibit the growth of human melanoma cells. J. Investig. Dermatol. 1995, 105, 248-253. [CrossRef] [PubMed]

84. Ribeiro, M.P.C.; Santos, A.E.; Custodio, J.B.A. The activation of the G protein-coupled estrogen receptor (GPER) inhibits the proliferation of mouse melanoma K1735-M2 cells. Chem. Biol. Interact. 2017, 277, 176-184. [CrossRef] [PubMed]

85. Matsuoka, H.; Tsubaki, M.; Yamazoe, Y.; Ogaki, M.; Satou, T.; Itoh, T.; Kusunoki, T.; Nishida, S. Tamoxifen inhibits tumor cell invasion and metastasis in mouse melanoma through suppression of PKC/MEK/ERK and PKC/PI3K/Akt pathways. Exp. Cell Res. 2009, 315, 2022-2032. [CrossRef]

86. Fellner, C. Ipilimumab (yervoy) prolongs survival in advanced melanoma: Serious side effects and a hefty price tag may limit its use. Pharm. Ther. 2012, 37, 503-530.

87. Larkin, J.; Chiarion-Sileni, V.; Gonzalez, R.; Grob, J.J.; Rutkowski, P.; Lao, C.D.; Cowey, C.L.; Schadendorf, D.; Wagstaff, J.; Dummer, R.; et al. Five-Year Survival with Combined Nivolumab and Ipilimumab in Advanced Melanoma. N. Engl. J. Med. 2019, 381, 1535-1546. [CrossRef] [PubMed]

88. Smalley, K.S. Why do women with melanoma do better than men? eLife 2018, 7. [CrossRef]

89. Natale, C.A.; Li, J.; Pitarresi, J.R.; Norgard, R.J.; Dentchev, T.; Capell, B.C.; Seykora, J.T.; Stanger, B.Z.; Ridky, T.W. Pharmacologic Activation of the G Protein-Coupled Estrogen Receptor Inhibits Pancreatic Ductal Adenocarcinoma. Cell. Mol. Gastroenterol. Hepatol. 2020, 10, 868-880.e1. [CrossRef]

90. He, Y.Y.; Cai, B.; Yang, Y.X.; Liu, X.L.; Wan, X.P. Estrogenic G protein-coupled receptor 30 signaling is involved in regulation of endometrial carcinoma by promoting proliferation, invasion potential, and interleukin- 6 secretion via the MEK/ERK mitogenactivated protein kinase pathway. Cancer Sci. 2009, 100, 1051-1061. [CrossRef]

91. Albanito, L.; Madeo, A.; Lappano, R.; Vivacqua, A.; Rago, V.; Carpino, A.; Oprea, T.I.; Prossnitz, E.R.; Musti, A.M.; Ando, S.; et al. $\mathrm{G}$ protein-coupled receptor 30 (GPR30) mediates gene expression changes and growth response to 17beta-estradiol and selective GPR30 ligand G-1 in ovarian cancer cells. Cancer Res. 2007, 67, 1859-1866. [CrossRef]

92. Henic, E.; Noskova, V.; Hoyer-Hansen, G.; Hansson, S.; Casslen, B. Estradiol attenuates EGF-induced rapid uPAR mobilization and cell migration via the G-protein-coupled receptor 30 in ovarian cancer cells. Int. J. Gynecol. Cancer 2009, 19, 214-222. [CrossRef] [PubMed]

93. Chimento, A.; De Luca, A.; Nocito, M.C.; Avena, P.; La Padula, D.; Zavaglia, L.; Pezzi, V. Role of GPER-Mediated Signaling in Testicular Functions and Tumorigenesis. Cells 2020, 9, 2115. [CrossRef]

94. Chevalier, N.; Hinault, C.; Clavel, S.; Paul-Bellon, R.; Fenichel, P. GPER and Testicular Germ Cell Cancer. Front. Endocrinol. 2021, 11, 600404. [CrossRef]

95. Chan, Q.K.; Lam, H.M.; Ng, C.F.; Lee, A.Y.; Chan, E.S.; Ng, H.K.; Ho, S.M.; Lau, K.M. Activation of GPR30 inhibits the growth of prostate cancer cells through sustained activation of Erk1/2, c-jun/c-fos-dependent upregulation of p21, and induction of G(2) cell-cycle arrest. Cell Death Differ. 2010, 17, 1511-1523. [CrossRef] [PubMed]

96. Siegfried, J.M.; Hershberger, P.A.; Stabile, L.P. Estrogen receptor signaling in lung cancer. Semin. Oncol. 2009, 36, 524-531. [CrossRef]

97. Ariazi, E.A.; Brailoiu, E.; Yerrum, S.; Shupp, H.A.; Slifker, M.J.; Cunliffe, H.E.; Black, M.A.; Donato, A.L.; Arterburn, J.B.; Oprea, T.I.; et al. The G protein-coupled receptor GPR30 inhibits proliferation of estrogen receptor-positive breast cancer cells. Cancer Res. 2010, 70, 1184-1194. [CrossRef] [PubMed]

98. Smith, H.O.; Leslie, K.K.; Singh, M.; Qualls, C.R.; Revankar, C.M.; Joste, N.E.; Prossnitz, E.R. GPR30: A novel indicator of poor survival for endometrial carcinoma. Am. J. Obstet Gynecol. 2007, 196, 386.e1-386.e9; discussion 386.e9-386.e11. [CrossRef] [PubMed]

99. Smith, H.O.; Arias-Pulido, H.; Kuo, D.Y.; Howard, T.; Qualls, C.R.; Lee, S.J.; Verschraegen, C.F.; Hathaway, H.J.; Joste, N.E.; Prossnitz, E.R. GPR30 predicts poor survival for ovarian cancer. Gynecol. Oncol. 2009, 114, 465-471. [CrossRef]

100. Chan, Y.T.; Lai, A.C.; Lin, R.J.; Wang, Y.H.; Wang, Y.T.; Chang, W.W.; Wu, H.Y.; Lin, Y.J.; Chang, W.Y.; Wu, J.C.; et al. GPER-induced signaling is essential for the survival of breast cancer stem cells. Int. J. Cancer 2020, 146, 1674-1685. [CrossRef]

101. Kalluri, R. The biology and function of fibroblasts in cancer. Nat. Rev. Cancer 2016, 16, 582-598. [CrossRef] 
102. Luo, H.; Yang, G.; Yu, T.; Luo, S.; Wu, C.; Sun, Y.; Liu, M.; Tu, G. GPER-mediated proliferation and estradiol production in breast cancer-associated fibroblasts. Endocr. Relat. Cancer 2014, 21, 355-369. [CrossRef] [PubMed]

103. Yang, K.; Yao, Y. Mechanism of GPER promoting proliferation, migration and invasion of triple-negative breast cancer cells through CAF. Am. J. Transl. Res. 2019, 11, 5858-5868. [PubMed]

104. De Francesco, E.M.; Pellegrino, M.; Santolla, M.F.; Lappano, R.; Ricchio, E.; Abonante, S.; Maggiolini, M. GPER mediates activation of HIF1alpha/VEGF signaling by estrogens. Cancer Res. 2014, 74, 4053-4064. [CrossRef] [PubMed]

105. Roskoski, R., Jr. Vascular endothelial growth factor (VEGF) signaling in tumor progression. Crit. Rev. Oncol. Hematol. 2007, 62, 179-213. [CrossRef]

106. De Francesco, E.M.; Sims, A.H.; Maggiolini, M.; Sotgia, F.; Lisanti, M.P.; Clarke, R.B. GPER mediates the angiocrine actions induced by IGF1 through the HIF-1alpha/VEGF pathway in the breast tumor microenvironment. Breast Cancer Res. 2017, 19, 129. [CrossRef]

107. Ren, J.; Guo, H.; Wu, H.; Tian, T.; Dong, D.; Zhang, Y.; Sui, Y.; Zhang, Y.; Zhao, D.; Wang, S.; et al. GPER in CAFs regulates hypoxia-driven breast cancer invasion in a CTGF-dependent manner. Oncol. Rep. 2015, 33, 1929-1937. [CrossRef]

108. Santolla, M.F.; Vivacqua, A.; Lappano, R.; Rigiracciolo, D.C.; Cirillo, F.; Galli, G.R.; Talia, M.; Brunetti, G.; Miglietta, A.M.; Belfiore, A.; et al. GPER Mediates a Feedforward FGF2/FGFR1 Paracrine Activation Coupling CAFs to Cancer Cells toward Breast Tumor Progression. Cells 2019, 8, 223. [CrossRef]

109. De Marco, P.; Lappano, R.; De Francesco, E.M.; Cirillo, F.; Pupo, M.; Avino, S.; Vivacqua, A.; Abonante, S.; Picard, D.; Maggiolini, M. GPER signalling in both cancer-associated fibroblasts and breast cancer cells mediates a feedforward IL1beta/IL1R1 response. Sci. Rep. 2016, 6, 24354. [CrossRef]

110. Whiteside, T.L. The role of immune cells in the tumor microenvironment. Cancer Treat. Res. 2006, 130, 103-124. [CrossRef]

111. Zamarron, B.F.; Chen, W. Dual roles of immune cells and their factors in cancer development and progression. Int. J. Biol. Sci. 2011, 7, 651-658. [CrossRef] [PubMed]

112. Aras, S.; Zaidi, M.R. TAMeless traitors: Macrophages in cancer progression and metastasis. Br. J. Cancer 2017, $117,1583-1591$. [CrossRef]

113. Lin, Y.; Xu, J.; Lan, H. Tumor-associated macrophages in tumor metastasis: Biological roles and clinical therapeutic applications. J. Hematol. Oncol. 2019, 12, 76. [CrossRef] [PubMed]

114. Notas, G.; Kampa, M.; Castanas, E. G Protein-Coupled Estrogen Receptor in Immune Cells and Its Role in Immune-Related Diseases. Front. Endocrinol. 2020, 11, 579420. [CrossRef] [PubMed]

115. Pernis, A.B. Estrogen and CD4+ T cells. Curr. Opin. Rheumatol. 2007, 19, 414-420. [CrossRef] [PubMed]

116. Straub, R.H. The complex role of estrogens in inflammation. Endocr. Rev. 2007, 28, 521-574. [CrossRef] [PubMed]

117. Wang, C.; Dehghani, B.; Magrisso, I.J.; Rick, E.A.; Bonhomme, E.; Cody, D.B.; Elenich, L.A.; Subramanian, S.; Murphy, S.J.; Kelly, M.J.; et al. GPR30 contributes to estrogen-induced thymic atrophy. Mol. Endocrinol. 2008, 22, 636-648. [CrossRef] [PubMed]

118. Isensee, J.; Meoli, L.; Zazzu, V.; Nabzdyk, C.; Witt, H.; Soewarto, D.; Effertz, K.; Fuchs, H.; Gailus-Durner, V.; Busch, D.; et al. Expression pattern of $G$ protein-coupled receptor 30 in LacZ reporter mice. Endocrinology 2009, 150, 1722-1730. [CrossRef] [PubMed]

119. Brunsing, R.L.; Owens, K.S.; Prossnitz, E.R. The G protein-coupled estrogen receptor (GPER) agonist G-1 expands the regulatory T-cell population under TH17-polarizing conditions. J. Immunother. 2013, 36, 190-196. [CrossRef] [PubMed]

120. Brunsing, R.L.; Prossnitz, E.R. Induction of interleukin-10 in the T helper type 17 effector population by the G protein coupled estrogen receptor (GPER) agonist G-1. Immunology 2011, 134, 93-106. [CrossRef]

121. Niino, M.; Hirotani, M.; Fukazawa, T.; Kikuchi, S.; Sasaki, H. Estrogens as potential therapeutic agents in multiple sclerosis. Cent. Nerv. Syst. Agents Med. Chem. 2009, 9, 87-94. [CrossRef] [PubMed]

122. Wang, C.; Dehghani, B.; Li, Y.; Kaler, L.J.; Proctor, T.; Vandenbark, A.A.; Offner, H. Membrane estrogen receptor regulates experimental autoimmune encephalomyelitis through up-regulation of programmed death 1. J. Immunol. 2009, 182, $3294-3303$. [CrossRef] [PubMed]

123. Blasko, E.; Haskell, C.A.; Leung, S.; Gualtieri, G.; Halks-Miller, M.; Mahmoudi, M.; Dennis, M.K.; Prossnitz, E.R.; Karpus, W.J.; Horuk, R. Beneficial role of the GPR30 agonist G-1 in an animal model of multiple sclerosis. J. Neuroimmunol. 2009, 214, 67-77. [CrossRef]

124. Meyer, M.R.; Fredette, N.C.; Howard, T.A.; Hu, C.; Ramesh, C.; Daniel, C.; Amann, K.; Arterburn, J.B.; Barton, M.; Prossnitz, E.R. G protein-coupled estrogen receptor protects from atherosclerosis. Sci. Rep. 2014, 4, 7564. [CrossRef] [PubMed]

125. Harding, A.T.; Goff, M.A.; Froggatt, H.M.; Lim, J.K.; Heaton, N.S. GPER1 is required to protect fetal health from maternal inflammation. Science 2021, 371, 271-276. [CrossRef]

126. Jacenik, D.; Beswick, E.J.; Krajewska, W.M.; Prossnitz, E.R. G protein-coupled estrogen receptor in colon function, immune regulation and carcinogenesis. World J. Gastroenterol. 2019, 25, 4092-4104. [CrossRef] [PubMed]

127. Davis, K.E.; Carstens, E.J.; Irani, B.G.; Gent, L.M.; Hahner, L.M.; Clegg, D.J. Sexually dimorphic role of G protein-coupled estrogen receptor (GPER) in modulating energy homeostasis. Horm. Behav. 2014, 66, 196-207. [CrossRef] [PubMed]

128. Santos, R.S.; de Fatima, L.A.; Frank, A.P.; Carneiro, E.M.; Clegg, D.J. The effects of 17 alpha-estradiol to inhibit inflammation in vitro. Biol. Sex Differ. 2017, 8, 30. [CrossRef] 
129. Wei, T.; Chen, W.; Wen, L.; Zhang, J.; Zhang, Q.; Yang, J.; Liu, H.; Chen, B.W.; Zhou, Y.; Feng, X.; et al. G protein-coupled estrogen receptor deficiency accelerates liver tumorigenesis by enhancing inflammation and fibrosis. Cancer Lett. 2016, 382, 195-202. [CrossRef]

130. Bussard, K.M.; Mutkus, L.; Stumpf, K.; Gomez-Manzano, C.; Marini, F.C. Tumor-associated stromal cells as key contributors to the tumor microenvironment. Breast Cancer Res. 2016, 18, 84. [CrossRef]

131. Rybinska, I.; Agresti, R.; Trapani, A.; Tagliabue, E.; Triulzi, T. Adipocytes in Breast Cancer, the Thick and the Thin. Cells 2020, 9 , 560. [CrossRef] [PubMed]

132. Divella, R.; De Luca, R.; Abbate, I.; Naglieri, E.; Daniele, A. Obesity and cancer: The role of adipose tissue and adipo-cytokinesinduced chronic inflammation. J. Cancer 2016, 7, 2346-2359. [CrossRef]

133. Bougaret, L.; Delort, L.; Billard, H.; Le Huede, C.; Boby, C.; De la Foye, A.; Rossary, A.; Mojallal, A.; Damour, O.; Auxenfans, C.; et al. Adipocyte/breast cancer cell crosstalk in obesity interferes with the anti-proliferative efficacy of tamoxifen. PLoS ONE 2018, 13, e0191571. [CrossRef]

134. Blucher, C.; Stadler, S.C. Obesity and Breast Cancer: Current Insights on the Role of Fatty Acids and Lipid Metabolism in Promoting Breast Cancer Growth and Progression. Front. Endocrinol. 2017, 8, 293. [CrossRef] [PubMed]

135. Lengyel, E.; Makowski, L.; DiGiovanni, J.; Kolonin, M.G. Cancer as a Matter of Fat: The Crosstalk between Adipose Tissue and Tumors. Trends Cancer 2018, 4, 374-384. [CrossRef]

136. Bauza-Thorbrugge, M.; Rodriguez-Cuenca, S.; Vidal-Puig, A.; Galmes-Pascual, B.M.; Sbert-Roig, M.; Gianotti, M.; Llado, I.; Proenza, A.M. GPER and ERalpha mediate estradiol enhancement of mitochondrial function in inflamed adipocytes through a PKA dependent mechanism. J. Steroid Biochem. Mol. Biol. 2019, 185, 256-267. [CrossRef]

137. Zhu, P.; Yuen, J.M.; Sham, K.W.; Cheng, C.H. GPER mediates the inhibitory actions of estrogen on adipogenesis in 3T3-L1 cells through perturbation of mitotic clonal expansion. Gen. Comp. Endocrinol. 2013, 193, 19-26. [CrossRef] [PubMed]

138. Bowers, L.W.; Rossi, E.L.; O'Flanagan, C.H.; deGraffenried, L.A.; Hursting, S.D. The Role of the Insulin/IGF System in Cancer: Lessons Learned from Clinical Trials and the Energy Balance-Cancer Link. Front. Endocrinol. 2015, 6, 77. [CrossRef]

139. Weissenborn, C.; Ignatov, T.; Ochel, H.J.; Costa, S.D.; Zenclussen, A.C.; Ignatova, Z.; Ignatov, A. GPER functions as a tumor suppressor in triple-negative breast cancer cells. J. Cancer Res. Clin. Oncol. 2014, 140, 713-723. [CrossRef]

140. Weissenborn, C.; Ignatov, T.; Poehlmann, A.; Wege, A.K.; Costa, S.D.; Zenclussen, A.C.; Ignatov, A. GPER functions as a tumor suppressor in MCF-7 and SK-BR-3 breast cancer cells. J. Cancer Res. Clin. Oncol. 2014, 140, 663-671. [CrossRef]

141. Liang, S.; Chen, Z.; Jiang, G.; Zhou, Y.; Liu, Q.; Su, Q.; Wei, W.; Du, J.; Wang, H. Activation of GPER suppresses migration and angiogenesis of triple negative breast cancer via inhibition of NF-kappaB/IL-6 signals. Cancer Lett. 2017, 386, 12-23. [CrossRef] [PubMed]

142. Wang, C.; Li, J.; Ye, S.; Zhang, Y.; Li, P.; Wang, L.; Wang, T.H. Oestrogen Inhibits VEGF Expression And Angiogenesis In Triple-Negative Breast Cancer By Activating GPER-1. J. Cancer 2018, 9, 3802-3811. [CrossRef]

143. Girgert, R.; Emons, G.; Grundker, C. Inactivation of GPR30 reduces growth of triple-negative breast cancer cells: Possible application in targeted therapy. Breast Cancer Res. Treat. 2012, 134, 199-205. [CrossRef]

144. Yu, T.; Liu, M.; Luo, H.; Wu, C.; Tang, X.; Tang, S.; Hu, P.; Yan, Y.; Wang, Z.; Tu, G. GPER mediates enhanced cell viability and motility via non-genomic signaling induced by 17 beta-estradiol in triple-negative breast cancer cells. J. Steroid Biochem. Mol. Biol. 2014, 143, 392-403. [CrossRef] 